\title{
Trapping, restraint and clinical-morphological traits of wild canids (Carnivora, Mammalia) from the Brazilian Cerrado
}

\author{
Nelson H. de A. Curi \& Sônia A. Talamoni \\ Programa de Pós-Graduação em Zoologia de Vertebrados, Pontifícia Universidade Católica de Minas Gerais. Avenida Dom \\ José Gaspar 500, prédio 41, 30535-610 Belo Horizonte, M inas Gerais, Brasil. E-mail: nelsoncuri@terra.com.br
}

\begin{abstract}
This article presents a simple, safe and efficient method for the capture and chemical immobilization of three species of wild canids from the Serra do Cipó National Park region, in the Cerrado biome of Southeastern Brazil. Morphological measurements and anesthesia data obtained during the captures are also described. Such data are essential due to the necessity for invasive research for monitoring programs, clinical cases analysis, and ecological or epidemiological investigations in wild or captive Neotropical canid populations. KEY WORDS. Anesthesia; biometry; Canidae; capture; Serra do Cipó National Park.
\end{abstract}

\begin{abstract}
RESUMO. Captura, imobilização e parâmetros clínicos e morfológicos de canídeos silvestres (Carnivora, Mammalia) do Cerrado brasileiro. Este artigo apresenta um método simples, seguro e eficiente para a captura e imobilização química de três espécies de canídeos silvestres da região do Parque Nacional da Serra do Cipó, no bioma Cerrado do Sudeste brasileiro. Medidas morfológicas e dados de anestesia obtidos durante as capturas também são descritos. Tais dados são essenciais devido a necessidade de pesquisas invasivas para programas de monitoramento, análises de casos clínicos, e investigações ecológicas ou epidemiológicas em populações cativas ou de vida livre de canídeos neotropicais.
\end{abstract}

PALAVRAS-CHAVE. Anestesia; biometria; Canidae; Parque Nacional da Serra do Cipó.

The order Carnivora is one of the most endangered taxa among mammals in Brazil, and some canid species are listed as threatened by the Brazilian Institute of Natural Resources and Environment (MACHADO et al. 2005). Wild canid research is growing fast in number and data quality, recognizing the ecological importance and the delicate conservation status of this family. Nevertheless, more ecological and conservation data are still necessary. Therefore, information that is useful for Neotropical wild canid research is also a must for achieving conservation goals. In the Serra do Cipó National Park (PARNA Cipó) region three species of wild canids were recorded (CuRI et al. 2006): the maned wolf Chrysocyon brachyurus (Illiger, 1815), the crab-eating fox Cerdocyon thous (Linnaeus, 1766), and the hoary fox Lycalopex vetulus (Lund, 1842) (Canidae).

The maned wolf $C$. brachyurus is a solitary species that uses home ranges from $25 \mathrm{~km}^{2}$ (DIETZ 1984) up to $115 \mathrm{~km}^{2}$ (Rodrigues et al. 1998). The World Conservation Union (IUCN) Red List considered this species as near threatened in 2006. Habitat loss, road deaths, harvesting and disease are listed among the major threats to their conservation since the 90's (Ginsberg \& Macdonald 1990, Sillero-Zubiri \& Hoffmann 2004).

The crab-eating fox $C$. thous lives in pairs or small groups and is widely distributed and common in central South America
(EISEnberg \& RedFord 1999). Their generalist and opportunistic behavior allows tolerance to natural or disturbed habitats, and they were seen interacting with many other carnivore species, including domestic dogs and cats, while visiting villages during night activity (Courtenay et al. 2001). JuARez \& MarinhoFILHO (2002) estimated the home range of 1280 ha for one individual of this species.

The hoary fox $L$. vetulus is a small canid inhabiting open Cerrado areas in Central and Southeastern Brazil. It is sympatric to the other two mentioned canid species in some parts of their distribution area, but occupying different spatial and trophic niches because of the predominantly insectivore diet and preference for pastures and open areas. Home ranges observed for one female was 385 ha, a breeding pair occupies home ranges of $456 \mathrm{ha}$, and the species lives at $1.5 \mathrm{fox} \mathrm{km}^{2}$ density (Machado et al. 1998, Juarez \& Marinho-Filmo 2002, Jácomo et al. 2004, Courtenay et al. 2006). There is taxonomic controversy in literature, and the species is cited in three different genera: Pseudalopex (e.g. MACHADO et al. 1998, BININDAEmmonds et al. 1999, Courtenay et al. 2006), Lycalopex (e.g. FonseCA et al. 1996, ZrZAVy \& Ricankova 2004) and Dusicyon (e.g. GINSBERG \& Macdonald 1990, Courtenay et al. 1996, Jácomo et al. 2004). In this study we have adopted the name cited by ZRZAVY \& 
Ricankova (2004), Lycalopex vetulus. The species conservation status is practically unknown, being classified as data deficient by the IUCN Red List in 2006 (Dalponte \& Courtenay 2004).

There are many studies on trapping methods and anesthesia protocols recommended for African, North American and European canids (e.g. Telesco \& SovadA 2002), but few publications are available for South American canids. In this manuscript we report a capture method and a chemical restraint protocol for wild canid species from the Brazilian Cerrado, and data on biological parameters obtained during the captures, which can be useful for future investigations. The captures were performed as part of an epidemiological study of wild and domestic canids conducted in 2004-2005 around the Serra do Cipó National Park.

\section{MATERIAL AND METHODS}

\section{Study area}

The study was conducted at the Serra do Cipó National Park (PARNA Cipó) (1912'-1920'S, 4330'-43누'W, 1095-1485 $\mathrm{m})$, and the Morro da Pedreira Environmental Protection Area, which encircles the park. Both are situated in the southern Espinhaço Range, State of Minas Gerais, Brazil. PARNA Cipó was founded in 1984 with an area of 33800 ha, inside 154 km perimeter. Only $57 \%$ of the land area is regulated and this has resulted in the persistent presence of human habitation inside the Park. The M orro da Pedreira Environmental Protection Area (66200 ha, $400 \mathrm{~km}$ perimeter) was founded in 1990, and is designed to act as a buffer zone for PARNA Cipó.

The region is hilly; the soil is predominantly shallow and sandy, allowing many vegetal formations to grow, such as forest galleries, cerrado, veredas and altitude fields. Local climate is classified as altitude tropical, and shows well-marked dry (April to September) and rainy (October to March) seasons (Eterovick \& Fernandes 2001, Eterovick \& Sazima 2003). Mean temperature and rainfall are $21.2^{\circ} \mathrm{C}$ and $1622 \mathrm{~mm}$, respectively. The biological importance of Serra do Cipó rises mostly due to the fauna, containing many endemic and threatened vertebrate species (Eterovick \& Sazima 2003, Câmara \& Murta 2003).

Four districts and their surroundings were chosen for the captures. Cardeal Mota (CM) is located near to PARNA Cipó entrance, and $100 \mathrm{~km}$ away from Belo Horizonte, the state capital. Conceição do Mato Dentro (CMD) is located on the opposite (northeast) side of the Park, and is farther $(165 \mathrm{~km})$ from Belo Horizonte. Lapinha da Serra (LS) is a small district located $40 \mathrm{~km}$ west of the Park. São José da Serra (SJS) is near to the Park's southern boundaries.

\section{Captures}

Leg traps were not used because of the possibility of serious injury (FLEMING et al. 1998). Cage traps, $1.70 \mathrm{~m}$ long, $1.20 \mathrm{~m}$ high, and $0.70 \mathrm{~m}$ wide (designed for the largest species, the maned wolf) were made with $50 \mathrm{~mm}$ "metalon" bars and wavy wire fences ( $20 \mathrm{~mm}$ side mesh, $5 \mathrm{~mm}$ bottom mesh). The traps were dismountable, easy to transport, and were painted dark green. Each trap weighed about $100 \mathrm{~kg}$. The trigger system consisted of a nylon string $(0.70 \mathrm{~mm}$ diameter) linking the bait, suspended $50 \mathrm{~cm}$ from the bottom and $20 \mathrm{~cm}$ from the back of the trap. Two wooden pieces kept the door open, falling when the animals pulled the bait and the door locked when they were completely inside thetrap. The baits were $300 \mathrm{~g}$ of baked chicken pieces, without condiment, and remained for up to one week in local conditions. Small chicken pieces $( \pm 20 \mathrm{~g})$ and chicken oil were placed every 10-20 m away from the traps in all possible directions up to a maximum of $1 \mathrm{~km}$, to attract the animals. The capture periods were from May to October 2004 and from June to September 2005 (275 trap days effort). The dry season was preferred because of the increased probability of capture due to food constraints, and for the easier manipulation of animals and access to the capture sites. These were chosen for signs of activity, mainly feces and footprints (ChAME 2003, LIMA Borges \& Tomás 2004), wild canid sightings, reports from local habitants and information from IBAMA-PARNA Cipó staff. The traps were set insidea $10 \mathrm{~km}$ radius from the villages, al lowing daily trap checking, always with land owners permission and informing the regional police beforehand, thus avoiding mistaken interpretations about the objectives of the captures.

The traps, were set in quiet shaded places, and left open all day. They were checked twice daily, in the morning and at the end of the day, to avoid excessive heat, stress and dehydration of the captured animals. The traps remained in place at each point for two weeks on average. Four traps were used at a distance of 5 to $10 \mathrm{~km}$ from each other. All capture points were marked with a GPS device.

\section{Chemical restraint}

The captured wild canids were anesthetized with xilazine hydrochloride (2 $\mathrm{mg} / \mathrm{kg}$ ), and ketamine hydrochloride $(8 \mathrm{mg} /$ $\mathrm{kg}$ ), according to BARBIERS \& BUSH (1995), injected intramuscularly in femoral or scapular body areas, by home made $3 \mathrm{ml}$ darts with $40 \mathrm{~mm}$ length $\times 1.2 \mathrm{~mm}$ thickness needles, launched from a steel blowgun ( $1 \mathrm{~m}$ length $\times 13 \mathrm{~mm}$ internal diameter). The wild canids weight was visually estimated using one-kilogram intervals for the foxes and five-kilogram weight intervals for maned wolves. By this way, total doses of base salt for adult maned wolves (supposed 20 to $30 \mathrm{~kg}$ weight) were $40-60 \mathrm{mg}$ of xilazine and $160-240 \mathrm{mg}$ of ketamine, doses for adult hoary foxes (hypothetically $4 \mathrm{~kg}$ weight) were $8 \mathrm{mg}$ of xilazine and $32 \mathrm{mg}$ of ketamine, and for adult crab-eating foxes (supposed $5 \mathrm{~kg}$ weight) were $10 \mathrm{mg}$ of xilazine and $40 \mathrm{mg}$ of ketamine. Oven concentrated drugs (xilazine at $10 \%$ and ketamine at $20 \%$ ) were used to minimize the injected volume. Supplemental ketamine doses (2-4 mg/kg intramuscularly, or $1-1.5 \mathrm{mg} / \mathrm{kg}$ intravenously) were injected when necessary (foxes received $20 \mathrm{mg}$, and maned wolves received $100 \mathrm{mg}$ of ketamine maximum). Anesthesia monitoring (rectal temperature, heart and respiratory frequency measurements) was made during all the chemical restraint period, every 5-10 minutes. After clinical examination and biological samples collection (blood, urine, 
feces and hairs used in an invasive health evaluation, N.H.A. Curı, un published data), the animals were monitored until complete recovery, and then safely released into the wild.

\section{Clinical examination and morphological measurement}

Complete clinical examination (visual inspection of the skin, teeth, all mucous membranes, ears, footpads and toes; external palpation of thelimbs, neck, abdominal organs and lymph nodes; abdominal and thoracic auscultation) was performed on each animal, and clinical-physiological data were recorded in individual files. Concurrently, biometrical measurements were made according to RAMOS JúNIOR et al. (2003). A dynamometer (Pesola ${ }^{\circledR}, 50 \mathrm{~kg}$ capacity, $100 \mathrm{~g}$ precision) was used for weighing.

\section{Marking}

Captured wild canids were marked with a non-toxic black hair dye, males on the left flank and females on the right flank, with a 10 - $15 \mathrm{~cm}$ mark, making it easy to recognize previously captured animals. The mark remains for about three months, time enough to move the traps to other areas and thus avoid re-sampling, in the case of recaptures.

\section{RESULTS AND DISCUSSION}

The trapping method proved to be efficient, safe and relatively easy to use. Twenty-one adult wild canids from three species, besides other taxa (see Tab. I) were captured. Wild canid capture success was 7.6\% (21 animals/275 trap-days x 100), the same as observed for domestic dogs. Most of the captures $(89 \%, 42 / 47)$ were of wild and domestic canid species. Therefore, the method is strongly selective for Canidae.

It was also observed that in areas where more domestic dogs were captured, wild canids trapping was less, and vice-versa. Among wild canids, $C$. thous were captured moretimes, followed by $C$. brachyurus and $L$. vetulus. All captured animals werehealthy and clinically normal, and were safely released after recovering from restraint. Only two individuals (one $C$. thous and one $C$. brachyurus, both male) were recaptured weeks later, being recognized by the marks and immediately released. Among domestic carnivores, dogs were captured more often than cats, so this may be a reflection on the bait selected for canids, or low domestic cat densities in the area. Two bird species were trapped (Tab. I). With Cariama cristata (seriema) lesions occurred, such as snout hemorrhage caused by beating against the wire mesh of the trap. We recommend care in the case of accidental captures, even in target species stressed individuals, breeding or pregnant females (when recognizable). Immediate release or restraint for clinical examination or wound treatment may be necessary, and the presence and services of a specialized veterinarian are essential.

Biometrical data from wild canids are listed in table II, and data from anesthetic monitoring in table III. Lycalopex vetulus individuals $(n=2)$ in this study differed in some morphological aspects when compared to other studies (CourTENAY et al. 2006). The average weight of animals from Serra do Cipó region ( $3.95 \pm 0.07 \mathrm{~kg}$ ) was $15 \%$ greater than that of animals
Table I. Numbers and trapping success (number of captures/ trapping effort $\times 100 \%$ ) of wild canids, domestic carnivores and other species in Serra do Cipó region. Areas are namely: Cardeal Mota (CM), Conceição do Mato Dentro (CMD), Lapinha da Serra (LS) and São José da Serra (SJS). Captures performed from May to October 2004 and from June to September 2005. The trapping effort was 275 trap-days (100\%).

\begin{tabular}{lcccccc}
\hline \multicolumn{1}{c}{ Canids } & CM & CMD & LS & SJS & $\begin{array}{c}\text { Total (Trapping } \\
\text { success \%) }\end{array}$ \\
\hline Cerdocyon thous & 5 & 3 & 1 & 3 & $12(4.36)$ \\
Chrysocyon brachyurus & 6 & 1 & - & - & $7(2.54)$ \\
Lycalopex vetulus & 2 & - & - & - & $2(0.72)$ \\
Total wild canids & 13 & 4 & 1 & 3 & $21(7.63)$ \\
Canis familiaris & 4 & 9 & 6 & 2 & $21(7.63)$ \\
Felis catus & - & 1 & 1 & - & $2(0.72)$ \\
Didelphis aurita & - & 1 & - & - & $1(0.36)$ \\
Cathartes burrovianus & - & 1 & - & - & $1(0.36)$ \\
Cariama cristata & - & - & - & 1 & $1(0.36)$ \\
\hline Total & 17 & 16 & 8 & 6 & $47(17.09)$ \\
\hline
\end{tabular}

from Unaí, Minas Gerais (3.42 kg), and the shoulder height (39 cm) about 12\% higher than Unaí individuals $(34.8 \mathrm{~cm}$ ). The areas are approximately $500 \mathrm{~km}$ apart.

We recommend remote injection systems, preferably with blowguns, for free-ranging wild canid anesthetized in traps, because of their promptness, efficiency, and less potential to cause injuries and stress in the animals. The anesthetic protocol, despite originally developed for $\mathrm{C}$. brachyurus, has proven safe and efficient for the three canid species, with no significant differencesin the physiological parameters obtained. Only for L. vetulus the induction time was less, this can be attributed to an overestimation of weight, and the average heart frequency was higher, despite the small number of individuals captured $(n=2)$. Five animals (three $C$. thous and two $C$. Brachyurus) received supplementary doses of ketamine (see materials and methods), and this increased the recovering and release time. Only three animals vomited during sedation, two $C$. thous and one L. vetulus, but no complications arose in these cases. Most of the animals (12/21) vocalized when approached or on release, yet most of the $C$. thous $(8 / 12)$ did not, despite the fact that these species seemed the most stressed and agitated during capture. Baits were totally eaten by the animals, only two $\mathrm{C}$. thous ate it partially. Two $\mathrm{C}$. thous showed sudden recovery after 35 and 55 minutes of chemical restraint, and were monitored for some minutes until they disappeared into the vegetation, without any kind of injury.

The drugs used in this study are easily acquired and at a low cost for veterinarians and most of these professionals are able to use them. They are quick acting, resulting in sufficient immobilization, effective for sufficient duration, no tissue damage, minimum effect on cardio respiratory function, and calm recovery periods without the need for antidotes. These aspects make the protocol recommended here well suited for captures, 
Table II. Biometrical data of wild canids captured in the Serra do Cipó region, between May to October 2004 and June to September 2005. Data in centimeters unless indicated.

\begin{tabular}{|c|c|c|c|c|c|c|c|c|c|c|}
\hline & \multicolumn{4}{|c|}{ C. thous ( 7 males, 5 females) } & \multicolumn{4}{|c|}{ C. brachyurus (4 males, 3 females) } & \multicolumn{2}{|c|}{ L. vetulus ( 1 male, 1 female) } \\
\hline & A & SD & A male & A female & A & SD & A male & A female & A & SD \\
\hline Ear (external) & 8.1 & 1.32 & 8.13 & 8.16 & 17.86 & 1.70 & 17.75 & 18.00 & 6.85 & 0.07 \\
\hline Ear (internal) & 6.3 & 0.98 & 6.37 & 6.34 & 15.14 & 1.21 & 15.50 & 14.67 & 5.10 & 0 \\
\hline Eyes & 1.6 & 0.29 & 1.64 & 1.56 & 3.56 & 0.68 & 3.73 & 3.33 & 1.65 & 0.35 \\
\hline Inter-orbital & 3.0 & 0.43 & 3.14 & 3.00 & 6.23 & 0.80 & 6.15 & 6.33 & 2.05 & 0.49 \\
\hline Snout-temple & 14.6 & 1.51 & 14.76 & 14.60 & 25.51 & 2.30 & 26.90 & 23.67 & 11.70 & 0.42 \\
\hline Snout-sacrum & 65.4 & 3.77 & 66.80 & 64.10 & 99.86 & 7.67 & 102.30 & 96.67 & 56.50 & 0.71 \\
\hline Neck circumference & 24.2 & 1.97 & 24.92 & 23.50 & 36.86 & 3.24 & 39.00 & 34.00 & 20.50 & 0.71 \\
\hline Thorax circumference & 36.8 & 2.30 & 37.33 & 36.30 & 61.14 & 5.34 & 64.00 & 57.33 & 31.00 & 0 \\
\hline Abdominal circumference & 36.1 & 3.69 & 37.00 & 35.10 & 63.57 & 6.65 & 63.25 & 64.00 & 34.50 & 2.12 \\
\hline Tail & 32.7 & 2.89 & 32.92 & 32.50 & 48.07 & 3.45 & 49.13 & 46.67 & 32.50 & 3.54 \\
\hline PA width & 2.8 & 0.56 & 2.86 & 2.85 & 5.00 & 0.71 & 5.00 & 5.00 & 1.90 & 0.14 \\
\hline PA length & 6.2 & 1.94 & 6.36 & 6.15 & 9.29 & 1.38 & 9.50 & 9.00 & 4.70 & 1.84 \\
\hline PP width & 2.6 & 0.65 & 2.51 & 2.83 & 5.04 & 0.59 & 5.33 & 4.67 & 1.60 & 0 \\
\hline PP length & 4.3 & 0.71 & 4.38 & 4.17 & 9.35 & 0.76 & 9.28 & 9.50 & 3.50 & 0 \\
\hline Shoulder height & 37.2 & 2.26 & 37.57 & 36.60 & 84.17 & 6.24 & 87.75 & 77.00 & 39.00 & 0 \\
\hline Weight (Kg) & 5.3 & 0.51 & 5.49 & 5.12 & 25.00 & 2.84 & 27.00 & 22.33 & 3.95 & 0.07 \\
\hline
\end{tabular}

(A) Average, (SD) standard deviation, (PA) foreleg, (PP) hind leg.

Table III. Anesthetic monitoring of wild canids captured in the Serra do Cipó region, between May to October 2004 and June to September 2005.

\begin{tabular}{|c|c|c|c|c|c|c|c|c|c|c|}
\hline & \multicolumn{4}{|c|}{ C. thous ( 7 males, 5 females) } & \multicolumn{4}{|c|}{ C. brachyurus ( 4 males, 3 females) } & \multicolumn{2}{|c|}{ L. vetulus (1 male, 1 female) } \\
\hline & A & SD & A male & A female & A & $\mathrm{SD}$ & A male & A female & A & SD \\
\hline Induction (min) & 7.6 & 5.4 & 7.1 & 8.3 & 6.7 & 2.8 & 8.1 & 4.8 & 2.8 & 0.4 \\
\hline Working (min) & 61.8 & 22.6 & 65.5 & 57.4 & 66.0 & 31.5 & 62.0 & 71.3 & 61.5 & 2.1 \\
\hline Recovery and release (min) & 98.2 & 36.0 & 97.0 & 99.6 & 145.1 & 53.2 & 164.3 & 119.7 & 125.0 & 35.4 \\
\hline Heart frequency (bpm) & 74.4 & 8.1 & 71.7 & 78.1 & 75.0 & 13.2 & 79.0 & 69.7 & 101.0 & 7.1 \\
\hline Breathe frequency (mpm) & 25.3 & 8.7 & 21.5 & 30.6 & 18.4 & 3.1 & 19.1 & 17.4 & 23.5 & 7.8 \\
\hline Rectal temperature $(\stackrel{\circ}{ } \mathrm{C})$ & 38.7 & 0.6 & 38.2 & 38.6 & 37.1 & 0.7 & 37.5 & 36.6 & 38.4 & 0.5 \\
\hline Vocalization * & $4 / 12$ & - & - & - & $6 / 7$ & - & - & - & $2 / 2$ & - \\
\hline Vomit & $2 / 12$ & - & - & - & $0 / 7$ & - & - & - & $1 / 2$ & - \\
\hline Bait eating & $9 / 12$ & - & - & - & $7 / 7$ & - & - & - & $2 / 2$ & - \\
\hline Supplemental anesthesia & $3 / 12$ & - & - & - & $2 / 7$ & - & - & - & $0 / 2$ & - \\
\hline
\end{tabular}

(A) Average, (SD) standard deviation, (*) during approximation or recovery.

clinical evaluations, biological samples collection and other quick and less invasive procedures in free-ranging wild canids from the Brazilian Cerrado, and it may also be tested and used for other canid species.

\section{ACKNOWLEDGEMENTS}

To Fundação O Boticário de Proteção à Natureza for the financial support; to IBAMA for license conceded (license number 016/2004) and for help in field activities; to PUC-Minas staff for manufacturing the traps; to Andrew Linghorn for English revision; to Leonardo Melo Barreto de Carvalho, Eliana Duarte Rocha and Cecília Barreto, and all the volunteer students who assisted in the field work; and for all land owners and habitants of the Serra do Cipó. We also wish to thank the anonymous reviewers, for their helpful comments on this manuscript.

\section{REFERENCES}

Barbiers, R. \& M. Bush. 1995. Medical management of maned wolves, p. 52-66. In: N.B. Fletchall; M. Rodden \& S. Taylor (Eds). Husbandry manual for the maned wolf Chrysocyon 
brachyurus. Washington, Smithsonian Institution Press, 75p.

Bininda-Emmonds, O.R.P.; J.L. Gittleman \& A. Purvis. 1999. Building largetrees by combining phylogenetic information: a complete phylogeny of the extant Carnivora (Mammalia). Biological Review, Cambridge, 74: 143-175.

CÂmara, E.M.V. \& R. Murta. 2003. Mamíferos da Serra do Cipó. Belo Horizonte, Editora PUC Minas, 127p.

Chame, M. 2003. Terrestrial mammal feces: a morphometric summary and description. Memórias do Instituto Oswaldo Cruz, Rio de Janeiro, 98 (1): 71-94.

Courtenay, O.; E.W. Santana; P.J. Jonson; I.A.B. Vasconcelos \& A.W. VAsConcelos. 1996. Visceral leishmaniasis in the hoary zorro Dusicyon vetulus: a case of mistaken identity. Transactions of the Royal Society of Tropical Medicine and Hygiene, London, 90: 498-502.

Courtenay, O.; R.J. Quinnel \& W.S.K. Chalmers. 2001. Contact rates between wild and domestic canids: no evidence of parvovirus or canine distemper virus in crab-eating foxes. Veterinary Microbiology, Orlando, 81: 9-19.

Courtenay, O.; D.W.Macdonald; S. Gillingham; G. Almeida \& R. DiAs. 2006. First observations on South America's largely insectivorous canid: the hoary fox (Pseudalopex vetulus). Journal of Zoology, London, 268: 45-54.

Curi, N.H.A.; I. Miranda \& S.A. Talamonı. 2006. Serologic evidence of Leishmania infection in free-ranging wild and domestic canids around a Brazilian National Park. Memórias do Instituto Oswaldo Cruz, Rio de Janeiro, 101 (1): 99-101.

Dalponte, J. \& O. Courtenay. 2004. Pseudalopex vetulus. In: IuCN (Ed.). IUCN red list of threatened species. Available in the Word WideWeb at: http://www.iucnredlist.org [Accessed on 06.XI.2006].

DietZ, J.M. 1984. Ecology and social organization of the maned wolf (Chrysocyon brachyurus). Smithsonian Contributions to Zoology, Washington, 392: 1-51.

Eisenberg, J.F. \& K.H. Redford. 1999. Mammals of the neotropics. The Central Neotropics. Chicago, University of Chicago Press, 609p.

Eterovick, P.C. \& W. FernANDES. 2001. Tadpole distribution within montane meadow streams at the Serra do Cipó, southeastern Brazil: ecological or phylogenetic constraints? Journal of Tropical Ecology, Cambridge, 17: 683-693.

Eterovick, P.C. \& I. Sazima. 2003. Anfíbios da Serra do Cipó. Belo Horizonte, Editora PUC Minas, 152p.

Fleming, P.J.S.; L.R. Allen \& P.D. Berghout. 1998. The performance of wild-canid traps in Australia: efficiency, selectivity and trap-related injuries. Wildlife Research, Victoria, 25: 327-
338.

Fonseca, G.A.B.; G. Herrmann; Y.L.R. Leite; R.A. Mittermeier; A.B. RYLANDS \& J.L. PATTON. 1996. Lista anotada dos mamíferos do Brasil. Belo Horizonte, Conservation International, Fundação Biodiversitas, 38p.

GINSBERG, J.R. \& D.W. MACDONALD. 1990. Foxes, wolves, jackals and dogs: an action plan for the conservation of canids. Gland, IUCN/SSC Canid Specialist Group \& IUCN/SSC Wolf Specialist Group, 117p.

JÁcomo, A.T.A.; L. Silveira \& J.A.F. Diniz-Filho. 2004. Niche separation between the maned wolf (Chrysocyon brachyurus), the crab-eating fox (Dusicyon thous) and the hoary fox (Dusicyon vetulus) in central Brazil. Journal of Zoology, London, 262: 99-106.

JuAREZ, K.M. \& J. Marinho-Filho. 2002. Diet, habitat use, and home ranges of sympatric canids in Central Brazil. Journal of Mammalogy, Lawrence, 83: 925-933.

Lima Borges, P.A. \& W.M. Tomás. 2004. Guia de rastros e outros vestígios de mamíferos do Pantanal. Corumbá, Embrapa Pantanal, 139p.

Machado, A.B.M.; G.A.B. da Fonseca; R.B. Machado; L.M.S. Aguiar \& L. V. Lins. 1998. Livro vermelho das espécies ameaçadas de extinção da fauna de Minas Gerais. Belo Horizonte, Fundação Biodiversitas, 605p.

Machado, A.B.M.; C.S. Martins \& G.M. Drummond. 2005. Lista da fauna brasileira ameaçada de extinção: incluindo as espécies quase ameaçadas e deficientes em dados. Belo Horizonte, Fundação Biodiversitas, 160p.

Ramos Júnior, V.A.; C. Pessuti \& C.A.F.S. Chieregatto. 2003. Guia de identificação dos canídeos silvestres brasileiros. Sorocaba, Comunicação Ambiental, 35p.

Rodrigues, F.H.G.; A. Hass; A.C.R. Lacerda \& R.L.S.C. Grando. 1998. Biologia e conservação do lobo-guará na Estação Ecológica de Águas Emendadas. Anais do Seminário "Pesquisa em Unidades de Conservação". Série Registros do Instituto Florestal, São Paulo, 2: 28-42.

Sillero-Zubiri, C. \& M. Hoffmann. 2004. Chrysocyon brachyurus. In: IUCN (Ed.). IUCN red list of threatened species. Available in the Word Wide Web at: http://www.iucnredlist.org [Accessed on 06.XI.2006].

Telesco, R.L. \& M.A. SovadA. 2002. Immobilization of swift foxes with ketamine hydrochloride-xilazine hydrochloride. Journal of Wildlife Diseases, Stanford, 38 (4): 764-768.

Zrzavy, J. \& V. Ricankova. 2004. Phylogeny of recent Canidae (Mammalia, Carnivora): relative reliability and utility of morphological and molecular datasets. Zoologica Scripta, Göteborg, 33 (4): 311-333.

Received in 15.V.2006; accepted in 06.XI.2006.

Revista Brasileira de Zoologia 23 (4): 1148-1152, dezembro 2006 